\title{
SUCCESS OF MATALE REGIONAL ECONOMIC ADVANCEMENT PROJECT (MREAP) AS POVERTY ALLEVIATION PROJECT
}

\author{
P. W. N. A. KUMARI \\ Department of Finance \\ Faculty of Commerce and Management Studies \\ University of Kelaniya, Sri Lanka \\ niroshak@kln.ac.lk \\ P. J. KUMARASINGHE \\ Department of Business Economics \\ Faculty of Management Studies and Commerce \\ University of Sri Jayewardhanepura, Sri Lanka
}

\begin{abstract}
This paper intended to assess the impact of microfinance on poverty alleviation in Matale district and identify the influence of macroeconomic condition on the net impact of microfinance. For that purpose Matale Regional Economic Advancement Project (MREAP) which was funded by International Fund for Agricultural Development (IFAD) was selected and sample consisted with 100 households who received the microcredit from MREAP. Descriptive statistics and one sample t-statistics revels that microcredit facilities help these beneficiaries to move for higher income ladders and though the nominal income of the beneficiaries has increased macroeconomic condition prevailed in Sri Lanka hampered the real benefit. Therefore, this study highlighted the importance of healthy economic condition in Si Lanka. Without health economic condition Si Lanka unable to reap the maximum benefit from the donor funds.
\end{abstract}

Keywords: Microfinance, Poverty

\section{Introduction}

Among the countries in the Asian region, India has been achieving a tremendous improvement in economic development and this rapid development in Indian economy has become a challenge even to some of the industrialized countries like China and Japan. Research and other innovative studies done in India have made a massive contribution to the achievements of India. Because India has paid due attention to all the layers of the population 
in conducting research and other activities related to micro financing activities, India could be cited as an example.

Being a small country in the neighborhood of India, Sri Lanka, has learned many lessons from India. Sri Lanka is still struggling hard to find out the correct mechanism to achieve the development targets mentioned in the policy agenda of the present government that is the "Mahinda Chinthana" that is to be the miracle of the Asia in terms of economic development. Paying due attention to all aspects of economic development is a vital thing in order to achieve that policy goal.

One of the major problems that the county is facing today is poverty. According to the Household Income and Expenditure Survey- 2006/07 conducted by Department of Census and Statistics 2009 (DCS), Sri Lanka's Poverty Headcount Ratio (PHR), urban PHR, rural PHR and estate PHR were 15.2\%, 6.7\%, $15.7 \%$ and 32\% respectively. Household income and expenditure survey conducted by the Department of Census and Statistics (2011) in 2009/10 specifies that the national level poverty head count index in Sri Lanka was 8.9\% while the corresponding values of the urban, rural and estate sectors were $5.3 \%, 9.4 \%$ and $11.4 \%$ respectively. When results of these two surveys were compared it is evident that there is a statistically significant reduction in poverty in Sri Lanka. But yet a significant number of people are facing many problems due to poverty.

Virtually, these values do not portrait the income disparity that is prevailing between rural and urban sectors. However, when the share of income to total household income in different categories is examined it is very clear that Sri Lanka is experiencing a huge income disparity. In addition to that, during the $2009 / 2010$ survey period the poorest $20 \%$ of the populations in Sri Lanka had received only $4.5 \%$ of the total income while the richest $20 \%$ had enjoyed around $54.1 \%$ of the total income of the county. This clearly specifies the income disparity that was prevailing between the poor and the rich categories of the population. Even though data presented in Table 1 shows that the PHR has reduced significantly, poor people enjoy relatively a small amount of the total income yet. The above facts confirm the statement that Sri Lanka is still struggling with the problem of poverty, the greatest curse of the mankind.

In Sri Lanka, different kinds of organizations have involved in poverty alleviation initiatives. Not only the government organizations but also a number of Non-Government Organizations (NGOs) are also participating actively in this process. Despite the numerous efforts devoted by various bodies to alleviate poverty in Sri Lanka poverty is yet one of the major problems. 
Though the microfinance is a major component in such programs whether those microfinance programs have really contributed to poverty alleviation is an important question to be answered. Every day new families do start their livelihood as new households and a part of them would fail to cross the poverty line. At the same time, some of the existing households get their livelihood improved crossing the poverty line successfully. While another group of households that walked out of the poverty trap return to the pool of poor people on a future day. For an example, children of poor families who started their livelihood as separate households amidst of financial difficulties could enter in to the poverty cycle on a future day. Though it is the reality, the level of attention paid to this phenomenon is insufficient. Not only that, but also some families that are not poor at present may become poor in future due to various reasons.

Even though this is the reality, most of the microfinance programs have developed targeting the people who are already in poverty without paying attention to develop a mechanism to prevent rich people becoming poor. When all above facts were boiled down, it is clear that poverty is a dynamic concept rather than a static concept.

\section{Identification of the Research Problem}

History of microfinance runs back to $16^{\text {th }}$ and $17^{\text {th }}$ centuries and its evolution has occurred in an informal way (Seible \& Dieter 2005) and, most of the researchers have recognized Bangladesh as the birth place of microfinance basically due to the massive contribution made by Professor Muhammad Yunus. The establishment of Grameen Bank in Bangladesh became a famous activity as it paid a significant attention to poverty reduction and women empowerment. This effort was recognized by awarding the Nobel Peace prize to Prof.Muhammad Yunus in 2006. (Meyer \& Nagarajan 2006). Even origin in Bangladesh dates back to more than 100 years and despite a large numbers of microfinance institutions (MFI) are working there Azad et al (2004) stated that poverty level has not reduced significantly.

During the long journey of microfinance in Sri Lanka massive numbers of microfinance programs have been launched targeting the rural population. Government organizations and local and international Non-Government Organizations (NGOs) have contributed significantly to the development of microfinance activities in Sri Lanka. Some of the microfinance programs were continued over long periods with different modifications. For an 
example the "Samurdhi" program was started as the "Janasaviya" program and still continues to support the needy people of the country.

Also, there is another category of microfinance programs which operates during a predetermined period. These projects terminate once the specified project period was over. Matale Regional Economic Advancement Project (MREAP) funded by the International Fund for Agricultural Development (IFAD) and the Participatory Rural Development Project (PRDP) implemented in Anuradhapura district under the financial assistance of the Asian Development Bank (ADB) are some examples for this category of development projects. Usually such projects have conducted ongoing monitoring studies while the project was implementing and terminal evaluation studies after the completion of the project. Results of monitoring and evaluation studies conducted were impressive as the project implementation was done under the strict supervision of a special team of individuals known as the project staff. But real impact of those foreign funded projects need to assess since it assure the effective utilization of the funds and at the same time it is very much essential to understand the impact of healthy macroeconomic condition for effectiveness of those foreign funded projects. Therefore research problem of this study is to

- Assess the impact of microfinance on poverty alleviation in Matale district and identify the influence of macroeconomic condition on the net impact of microfinance.

\section{Literature Review}

The most developed continent in the world relating to the microfinance activities is the Asian continent where we are living. This is based on the volume of MFI activities. (Lapeneu and Zeller 2001, Bedson, 2009). The way it was evolved and its tremendous development that occurred in the Asian region were recognized by the practitioners' all over the world through awarding of the Nobel peace award to professor Mohammad Yunus. Social, political and geographical coverage reflects the diversity of the microfinance industry in Asia (Bedson, 2009). Peoples Republic of China, India, Bangladesh, Sri Lanka and Pakistan are some of the countries which are actively engaged in microfinance activities. Not only that but also all other countries in the South Asia have reaped impressive benefits from microfinance related activities. It means that despite the social, political or any other difference, microfinance is equally important to the whole Asia. 
Even though discussions on microfinance activities in Sri Lanka are highly debatable yet, its origin dates back to more than 100 years. According to the Microfinance Industry's Report (2009) the establishment of the Thrift and Credit Co-operative Societies (TCCS) were done in 1906 under the Co-operative Societies Ordinance and that was the corner stone of this evolution. After its establishment, the TCCS reflected a down-turn in 1970 and because of that it was re-organized as the Co-operative Credit Societies (SANASA). Another milestone of the microfinance industry is the establishment of the Regional Rural Development Banks (RRDBs) covering all districts other than the North and the East (at the initial stage). These banks were maintained through the regional offices of the Central Bank of Sri Lanka located at Anuradhapura, Matale, Galle and, Badulla. The Kadurata Development Bank, the Sabaragamuwa Development Bank, and the Rajarata Development Bank were some of the RRDBs and all the regional development banks were merged in 2009 to form the Regional Development Bank (RDB). This new bank serves a wide range of needs of the needy people.

The government contribution to microfinance activities is at a precise level. About $65 \%$ of microcredit in Sri Lanka is provided through the government. The "Janasaviya" program was one of the large scale micro financing programs launched by the government and in 1995 and it was replaced with the "Samurdhi" program. The "Samurdhi" program is not merely a subsidy provider but also a promoter of micro savings, group based microcredit, and entrepreneurship trainings as well. (Microfinance Industry Report 2009).

Non-government organizations (NGOs) are also functioning in Sri Lanka. Involvement of the NGOs was highlighted during the post Tsunami rehabilitation projects and at present, a large number of NGOs are serving the poor in war affected areas. The Commercial Banks' contribution to microfinance commenced with the introduction of "Gamipubuduwa" program introduced by the Hatton National Bank in 1989. At present, most of the commercial banks are actively engaged in micro financing activities. So, the discussions on micro financing and conducting research related to various aspects of micro financing has begun to blossom in Sri Lanka.

Despite the proud microfinance history of more than 100 years, the growth of the microfinance industry in Sri Lanka was constrained due to the absence of required regulatory and supervisory systems. As responsible authorities are still engaged in the process of preparing a microfinance bill, various microfinance programs implemented in Sri Lanka were regulated and supervised by various authorities. For an example, the Co-operative Rural 
Banks (CRBs) are regulated by the Department of Co-operative Development while the RDBs are supervised by the Central Bank of Sri Lanka

Findings of Mark \& Khandker (1998) revealed that only 5\% or less of the beneficiaries could be able to up- lift their life by obtaining the funds from microfinance institutions and that is equal to $1 \%$ of whole population. He further questioned that whether such programs should be terminated or continue?

Microfinance has identified as an effective tool for poverty alleviation. But in real sense it basically serves the moderate poor and non poor category. The Poorest group does not receive any direct benefit out of this due to various reasons such as lack of skills, lack of technical knowhow and marketability of products and if they request for loan it is slowly for the consumption purposes (Thilakarathne 2005). Even though microfinance commenced as an effective tool in poverty alleviation, at present it is questionable whether it really in line with the founders expectation (Mark \& Khandker 1998, Thilakarathne 2005, Kondo et al 2008).

Discussing about the Sri Lankan context Colombage (2004) conducted research to identify the opportunities and constraints of microfinance as the poverty alleviation tool. According to his findings in Sri Lanka poor people not ready to take any risk there for they just continue their traditional business or the agricultural activities. Government needs provide the healthy macroeconomic conditions for microfinance activities within the country. Specially, price stability is must for the effective and efficient utilization of the microfinance (Colombage 2004).

Microfinance was more successful in its initial stage since at the outset consideration of micro finance was mainly serving the poor to climb the income ladder and even at presents taking various forms microfinance serves the economy. As Madheswaran and Dharmadhikary (2001) identified viability of non- farm economic activities, earning profit that would cover the interest rate of the loan and the marketing of products produced by the micro entrepreneurs as major problems associated with micro finance.

\section{Methodology}

Various researches have evaluated the impact of microfinance efforts. In general, as stated by Kondo et al (2008), the problem associated with this kind of evaluation is the selection of suitable counterfactual against which the treatment group is compared and according to them 
gold standard in impact evaluation is a randomized experiment. In this process treatment and the control groups are randomly selected.

Another most frequently used technique for research is quasi experiment method and if a researcher wanted to use the quasi experiment method that study should satisfy the following requirements. (1) availability of treated and untreated groups: (2) there must be a pretreatment and post treatment measure: (3) there must be an explicit model that project over time the difference between the treated and untreated group, given no treatment effect (Kenny, 1975), Quasi experimentation method compares the outcomes of an intervention with a simulation of what the outcome would have been, had there been no intervention Hulme (2000). Table 01 presents the common impact assessment methods used by various researches.

When sample survey method was used researcher should collect the quantifiable data from a representative sample. Using questionnaires data should be gathered about predetermined indicators from the respondents of both groups before and after the project intervention. Quantitative information collected from the treatment group can be compared with the relevant data collected from the control group.

Next commonly used impact assessment method is the rapid appraisal method. This method basically occupied through the use of focus group discussions, semi structured interviews with key informants, case studies, participant observations and the use of secondary data. Participant observation is basically done through qualitative techniques and mini scale samples.

Case study is the detailed analysis of a focus group. Since it is detailed analysis open ended questions are frequently used. Participatory learning and action is the method that is to be completed with the participation of intended beneficiaries. This method helps to acquainted with the opinions of the beneficiaries.

When selecting the best fitted impact assessment method following things should receive a due attention. (a) objectives of the assessment, (b) way of information use and whom it use, (c) required level of reliability, (d) complexity of the program, and (e) the availability of resources. Hulme (2000) 
Table 01: Common Impact Assessment Data Collection Methods

\begin{tabular}{ll}
\hline Method & Key features \\
\hline Sample Surveys & Collect quantifiable data through questionnaires. \\
& Usually a random sample and a matched control group \\
& are used to measure predetermined indicators before \\
& and after intervention \\
\hline Rapid appraisal & A range of tools and techniques developed originally as \\
& rapid rural appraisal (RRA).It involves the use of focus \\
& groups, semi structured interview with key informants, \\
& case studies, participant observation and secondary \\
& sources \\
Extended residence in a program community by field & researchers using qualitative techniques and mini scale \\
sample surveys & Detailed studies of a specific unit (a group, locality, \\
organization) involving open-ended questioning and the \\
preparation of "histories" \\
\hline Pase studies \\
The preparation, by the intended beneficiaries of a \\
program, of timelines, impact flow charts, village and \\
through group processes assisted by a facilitator. \\
\hline
\end{tabular}

Source: Hulme (2000)

A careful study of the method of impact assessment showed in Table 01 and their strength and weaknesses will help to select the best alternative to be used. Further, cost and time consideration of methodology selection says that it is feasible to select a mix of sample survey and the rapid appraisal as the best alternative for the study. Consideration on budget availability is also of paramount importance. The importance of budget consideration was stated by Hulme (2000) as follows.

"The design of an IA must be very closely related to the budget available: this may be a platitude but over ambitious designs continue to lead to poor quality studies or delays that make findings irrelevant". 
Therefore this study basically use both sample survey and rapid appraisal methods for the purpose of conducting impact analysis.

Sampling was done in two major steps. During the first step one project was selected purposively among from various projects funded by the different international donors. During this step Matale Regional Economic Advancement Project was selected because it is a project completed five years ago and this is the appropriate time to assess the long term sustainability of project interventions. For this purpose project area was divided into different groups based on the DS Divisions and then a random sample of 100 beneficiaries was selected using the loan register maintained by the project and another 100 non beneficiary group in the same villages selected as control group. Stud basically occupied descriptive statistics and t statistics as major data analysis techniques and SPSS was use as the data analysis tool in this study.

Most of the studies which aimed the evaluation of microfinance projects have employed descriptive statistics as the major analytical technique in their analyses. For examples, Rahaman \& Ahamad (2010) and ADB (2007) employed descriptive analysis in their studies.

\section{Discussion}

Table 02: Total Number of Loans Disbursed during the Project Period

\begin{tabular}{|l|c|c|c|c|c|c|c|}
\hline \multirow{2}{*}{ Amount (RS) } & \multicolumn{5}{|c|}{ Year } & \multirow{2}{*}{ Total } & \multirow{2}{*}{$\%$} \\
\cline { 2 - 8 } & $\mathbf{2 0 0 1}$ & $\mathbf{2 0 0 2}$ & $\mathbf{2 0 0 3}$ & $\mathbf{2 0 0 4}$ & $\mathbf{2 0 0 5}$ & & \\
\hline $0-5000$ & 14 & 1 & 2 & 0 & 16 & 33 & 0.89 \\
\hline $5001-10000$ & 123 & 11 & 50 & 0 & 29 & 213 & 5.76 \\
\hline $10001-20000$ & 354 & 64 & 141 & 4 & 119 & 682 & 18.44 \\
\hline $20001-50000$ & 379 & 455 & 697 & 33 & 338 & 1902 & 51.42 \\
\hline $50001-100000$ & 64 & 181 & 198 & 30 & 85 & 558 & 15.09 \\
\hline $100001-200000$ & 29 & 60 & 50 & 6 & 32 & 177 & 4.79 \\
\hline $200001-500000$ & 12 & 20 & 39 & 14 & 33 & 118 & 3.19 \\
\hline More than 500000 & 0 & 6 & 4 & 1 & 5 & 16 & 0.43 \\
\hline Total & 975 & 798 & 1181 & 88 & 657 & & \\
$(26 *)$ & $(22 *)$ & $(32 *)$ & $(02 *)$ & $(18 *)$ & 3699 & 100 \\
\hline
\end{tabular}

Source: Author Compiled

*Values in parentheses are percentages of the total number of loans disbursed

Table 02 present the annual loan disbursement of the MREAP and out of the total number of loans released $32 \%$ has released in 2003. The least percentage of loans was released in 2004. Total number of loans disbursed was 3699 and of which 51.42\% was between Rs.20, 001 and Rs 50,000. Percentage of loans disbursed which is grater that Rs 100,000 was only $8.41 \%$. This indicates that the majority of the loans disbursed were less than Rs. 100,000. (Figure 
01) and the majority of the loans were released during the first three years of the project (Table 02)

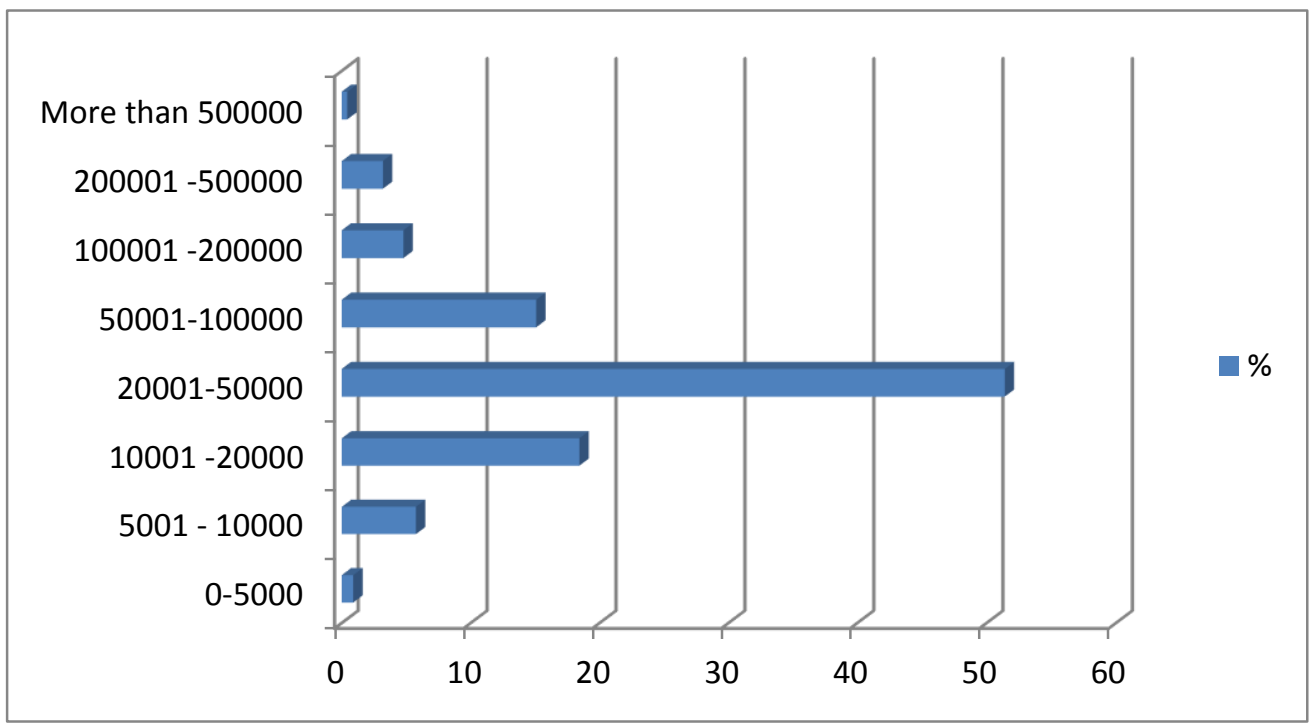

\section{Figure 01: Disbursements of loans}

Source: Author Compiled

One of the significance statistical measurements to analyze the impact of microfinance on income level is the use of one sample $t$ test. According to the one sample t-test as shown in the Table 03 mean value of the income of the respondents is Rs.23, 134.70. This mean value is the mean income of the households based on the field survey conducted by the researcher. But this mean value does not to give any statistical evidence on changes of income in the long term. Table 04 shows the one sample $t$ test for this analysis and according to that test value 15,280 is the mean income of the household at the of the post project evaluation and the present mean household income is Rs.23, 135 and the mean income of the household at the post project evaluation is statistically different from the mean income of the household at the existing stage of $5 \%$ level of significances. Changes in each income decline are presented in figure 02 .

Table 03: One-sample statistics

\begin{tabular}{|c|c|c|r|r|}
\hline & $\mathbf{N}$ & Mean & Std. Deviation & Std. Error Mean \\
\hline Income & 100 & $23,134.7000$ & $4,741.32221$ & 474.13222 \\
\hline
\end{tabular}

Source: Author Compiled 
Table 04: One sample test - Significance evaluation

\begin{tabular}{|c|c|c|c|c|c|c|}
\hline & \multicolumn{6}{|c|}{ Test Value $=15280$} \\
\hline & $\mathbf{T}$ & df & Sig. (2-tailed) & $\begin{array}{l}\text { Mean } \\
\text { Difference } \\
\text { of the } \\
\text { Difference } \\
\end{array}$ & $\begin{array}{r}95 \% \mathrm{Cc} \\
\text { Int }\end{array}$ & $\begin{array}{l}\text { Ifidence } \\
\text { rval }\end{array}$ \\
\hline & & & & & Lower & Upper \\
\hline Income & 16.6 & 99 & 0 & $7,854.7$ & $69,13.92$ & $8,795.48$ \\
\hline
\end{tabular}

Source: Author Compiled

Table 05: Changes of mean income of the households

\begin{tabular}{|r|r|r|r|r|}
\hline \multicolumn{1}{c|}{$\begin{array}{c}\text { Income } \\
\text { Category }\end{array}$} & Before & After & Difference & $\begin{array}{c}\text { \% } \\
\text { Difference }\end{array}$ \\
\hline 1 & 2,029 & 2,866 & 837 & 41.25 \\
\hline 2 & 3,699 & 4,977 & 1,278 & 34.55 \\
\hline 3 & 4,829 & 6,674 & 1,845 & 38.21 \\
\hline 4 & 5,942 & 8,711 & 2,769 & 46.6 \\
\hline 5 & 7,935 & 10,813 & 2,878 & 36.27 \\
\hline 6 & 9,875 & 13,800 & 3,925 & 39.75 \\
\hline 7 & 12,121 & 15,961 & 3,840 & 31.68 \\
\hline 8 & 14,818 & 19,603 & 4,785 & 32.29 \\
\hline 9 & 18,710 & 25,212 & 6,502 & 34.75 \\
\hline 10 & 31,121 & 43,726 & 12,605 & 40.5 \\
\hline & & & & \\
\hline
\end{tabular}

Source: Adopted from MREAP

According to the Table 05 it shows how the mean income of the each income deciles changes before and after the project intervention. When consider about the first income category their mean income was Rs.2029 and at the end of the project period it was Rs.2866.it shows the $41.25 \%$ of change. Highest mean income change could be experience in the $4^{\text {th }}$ income category and it was $46.60 \%$.as such there was significant changes in the mean income of each and every income categories. 


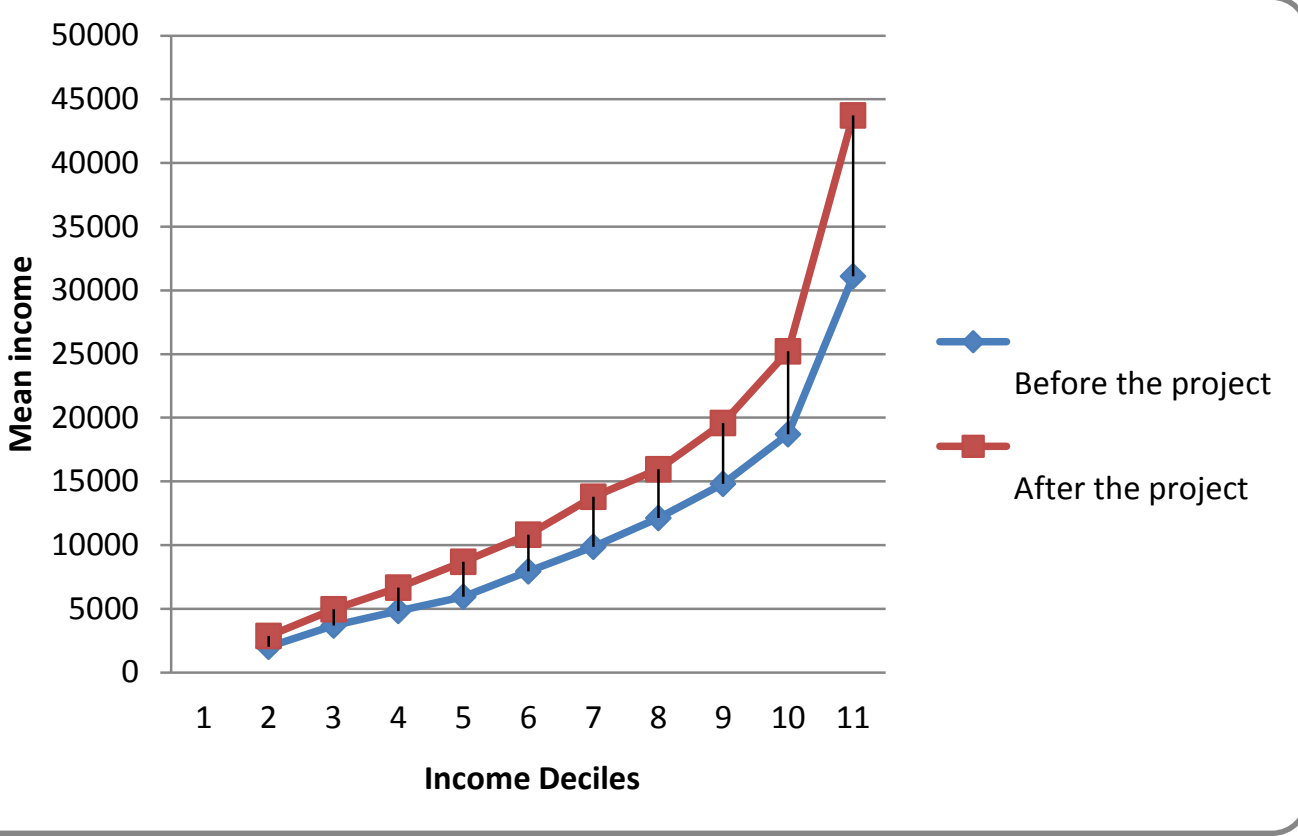

\section{Figure 02: Change of mean income}

Source: Author Compiled

\section{Analysis of the Real Income of the Households}

Analysis of the changes in real income of the beneficiaries before and after the project intervention is shown in the Table 06. For the purpose of calculating the real income of the household researcher used the Colombo Consumer Price Index and for year 2007 it was 163.10 and the based year was 2002 .

According to that the real mean income of the households has decreased in all income categories. It indicates the necessity of healthy economic condition for effective and efficient functioning of the microfinance activities. Colombage (2004) emphasized the importance of this fact or with the evidences from Sri Lanka. As he stated unfavorable economic conditions negatively influence not only on the poor consumers but also on the micro enterprises as well. High inflation, budget deficits, external payment disequilibrium are identified problems associated with the economy in Sri Lanka. This real income reduction of the household does not revealed that microfinance program did not make any influence on the income level of the households and it is a result of unhealthy. Figure 16 depicts these changes in real income of the households before and after the project. If huge fluctuations in economy are prevailing further interventions of foreign donors on microfinance projects also will affect negatively. Therefore, this signals the existing government about the effects of unsound macroeconomic policies of the government. 
Table 06: Changes in real mean income of the beneficiaries

\begin{tabular}{|c|c|c|}
\hline Income Category & Before the Project & After the Project \\
\hline 1 & $2,029.00$ & $1,757.20$ \\
\hline 2 & $3,699.00$ & $3,051.50$ \\
\hline 3 & $4,829.00$ & $4,091.97$ \\
\hline 4 & $5,942.00$ & $5,340.90$ \\
\hline 5 & $7,935.00$ & $6,629.68$ \\
\hline 6 & $9,875.00$ & $8,461.07$ \\
\hline 7 & $12,121.00$ & $9,786.02$ \\
\hline 8 & $14,818.00$ & $12,019.01$ \\
\hline 9 & $18,710.00$ & $15,458.00$ \\
\hline 10 & $31,121.00$ & $26,809.32$ \\
\hline
\end{tabular}

Source: Author Compiled

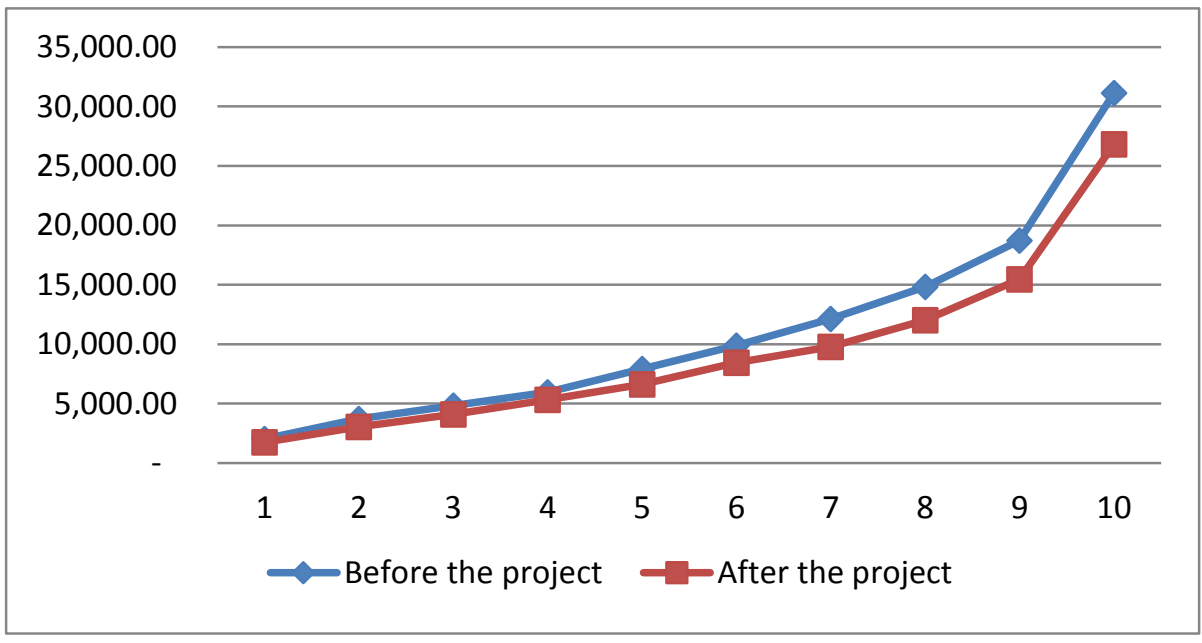

\section{Figure 03: Analysis of changes in real income}

Source: Author Compiled

Further researcher indended to analyse the precentage of reference persons below the poverty line.Therefore another new variable was computed.This new variable shows the difference between real per capita food and non food expenditure and the official poverty line of Matale distric. This new variable takes both the positive and negative values.If the variable is positive it indicates that those families per capita expenditure is higher than official povery line of Matale district and it means they could be treated as the household those who can meet the expenses of their montly food and non food items.If new variable takes negative value it means that those individuals could not meet their minimum monthly food and non food expenditures with their income .

Eventhogh the househlod income has incresed if they could not be able to meet their minimum requirements it does not help to increse the utility level of the people, futhers it is 
not mean that the living standerds of the people has impoved. Table 07 shows the precentage analysis of the above mentioned fact.

Table 07 : Difference between real food and non food expenditute and the official poverty line

\begin{tabular}{|l|r|}
\hline Category & Percentage \\
\hline Greater than (1500) & $2 \%$ \\
\hline$(1000)-(1500)$ & $14 \%$ \\
\hline$(500)-(1000)$ & $29 \%$ \\
\hline $0-(500)$ & $15 \%$ \\
\hline $0-500$ & $9 \%$ \\
\hline $501-1000$ & $7 \%$ \\
\hline $1001-1500$ & $10 \%$ \\
\hline $1501-2000$ & $9 \%$ \\
\hline $2001-2500$ & $5 \%$ \\
\hline Total & $100 \%$ \\
\hline
\end{tabular}

* values in paantheses ae negative

Source : Author Compiled

Table 07 has identified nine catogories of the above mentioned new variable.As mention above this catogorization shows the difference between real per capita monthly income and the official poverty line.According to that total precentage of people below the poverty line is $60 \%$ while people above the poverty line is only $40 \%$. Above analysis shows that though the microfinance has raised income of the household but still reasonable precentage of people are below the poverty line. So this is an obsevation that is notewothy as it signals to the policy makers to take necessry steps to strenghen the microfinace activities in Sri Lanka.

Further Figure 04 present this situation graphically.Value zero in this figure represents value of the official poverty line and negative values on the left hand side represent the respondents below the official provety line and the values on the right hand side are positve values and those represent the respondents above the poverty line. 


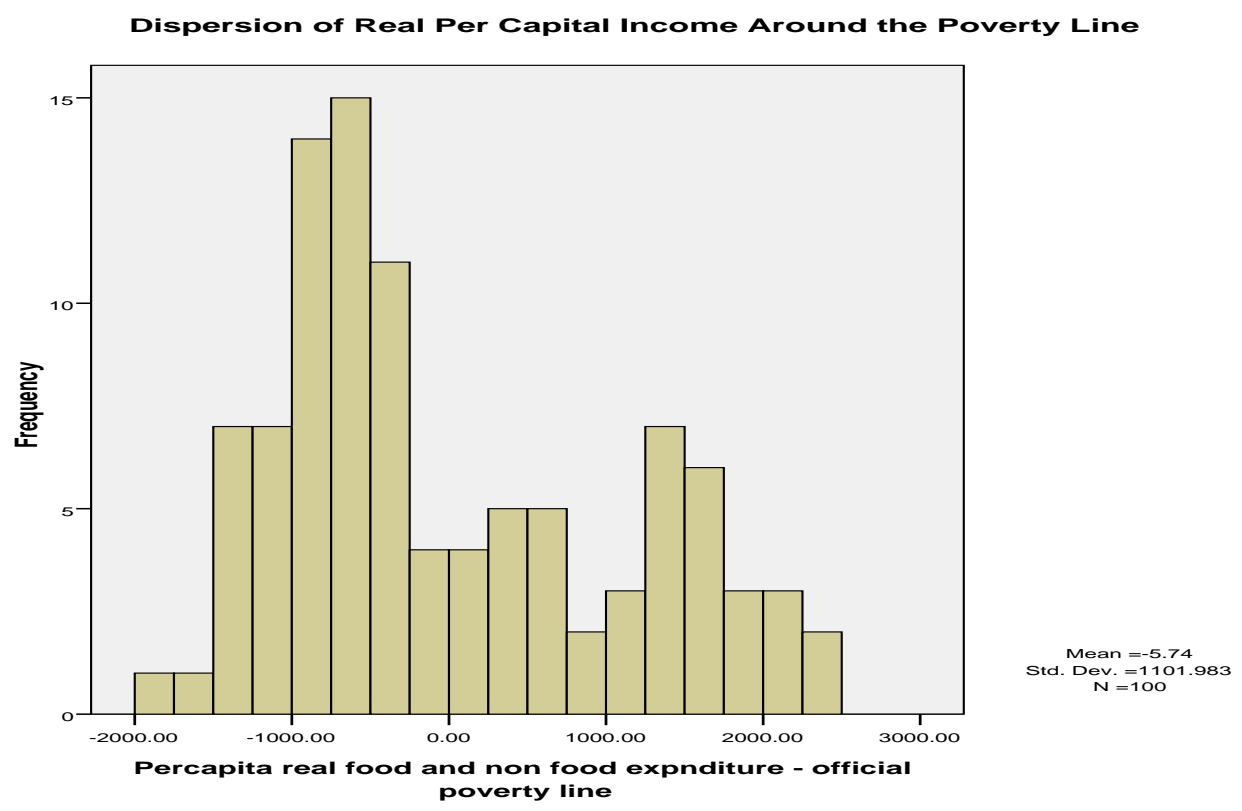

Figure 04 : Dispersion of real per capita income Source : Author Compiled

\section{Conclusion}

Study on microfinance project conducted by MREAP supported to ended up with significance finding on Sri Lankan Microfinance industry. According to the study microfinance facilities provided by MREAP supported to enhance the income of the people. Moe importantly finding of this study reveals that microfinance positive influence on peoples' lives was hampered due to the prevailing economic condition in Sri Lanka. Therefore even though nominal income of the households has increased due to the inflation in country household real income has affected. According to the analysis of household real food and non food expenditure still $60 \%$ of the respondents fall below the official poverty line.

Based on all the analysis it could be concluded that MREAP project was a successful project which help beneficiaries to alleviate the poverty but in the long run its impacts are weaken due to the non availability of continuous supervision and the unhealthy economic condition in country. Finally, researcher intended to propose further stud to stud the net impact of microfinance with the support of Difference in Difference (DID) methodology which is most commonly used for many impact studies. 


\section{References}

Asian Development Bank (ADB), 2007, 'Effect of Microfinance operations on poor rural households and the status of women.

Azad, ASMS \&Shamsuddoha M 2004, 'Assessing impact of micro finance on poverty alleviation-Bangladesh Perspective', Access date, < SSRN: http://ssrn.com/abstract=1302291>.

Bedson, J 2009, 'Microfinance in Asia trends, challenges and opportunities',

Colombage, SS 2004, 'Microfinance as an instrument for small enterprise development: opportunities and constraints', Occasional Papers: Number 52, Centre For Banking Studies, Central Bank of Sri Lanka.

Department of Census and Statistics 2011,'Household Income and Expenditure Survey 2009/10’, Final Report.

Department of Census and Statistics, 2009,'Household Income and Expenditure Survey 2006/07', Final Report.

Hulme, D 2000, 'Impact assessment methodologies for microfinance: theory, experience and better practice', World Development, vol. 28, no. 1, pp. $79-98$.

Kenny DA 1975, 'A Quasi-Experimental Approach to Assessing Treatment Effects in the Nonequivalent Control Group Design', Psychological Bulletin, vol. 82, no. 3, pp. 345-362.

Kondo, T, Orbeta, AJr, Dingcong, C \&Infantado, C 2008, 'Impact of microfinance on rural households in the Philippines', discussion paper series no .2008-05, Philippine Institute for Development Studies.

Lapeneu,C,and Zeller, M 2001, 'Distribution, Growth and Performance of Micro-finance Institutions in Africa, Asia and Latin America', Food Consumption and Nutrition Division Discussion Paper no. 114 (June). Washington D.C.: International Food Policy Research Institute. 
Madheswaran, S \&Dharmadhikary, A 2001,'Empowering Rural Women through Self-Help Groups: Lessons from Maharashtra Rural Credit Project', Indian Journal of Agricultural Economics, vol. 56, no3, pp. 427-43.

Mark, MP \&Khandker, SR 1998, 'The impact of group based credit programs on poor households in Bangladesh: does the gender of participants Matter?',Journal of Political Economy,vol.106, pp: 958-96.

Meyer RL \&Nagarajan, G 2006, 'Microfinance in developing countries: accomplishments, debates, and future directions', Agricultural Finance Review, vol. 66, no: 2 pp. 167 - 193.

Microfinance Industry Report 2009, Produced by GTZ ProMiS in collaboration with The Banking with the Poor Network

Rahman, MM \& Ahmad, F 2010, 'Impact of microfinance of IBBL on the rural poor's livelihood in Bangladesh: an empirical study', International journal of Islamic and Middle Eastern Finance and Management, vol.3, no.2, pp 168-190.

Seibel, and Dieter, H 2005, 'Does history matter? The old and the new world of Microfinance in Europe and Asia', working paper/University of Cologne, Development research center No.2005, 10

Thilakarathne, G, M 2005, 'Microfinance in Sri Lanka: A household level analysis of outreach and impact on poverty', A paper presented during the 4th PEP Research Network general Meeting Colombo. 